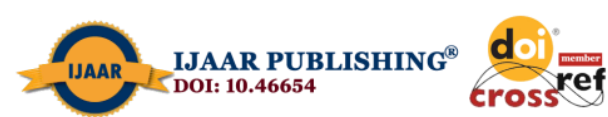

Journal DOI: www.doi.org/10.46654/RJMP

Research Journal of Management Practice | ISSN: 2782-7674

Vol. 1, Issue 3 (March, 2021) | www.ijaar.org

Article DOI: www.doi.org/10.46654/RJMP.1315

\title{
VALUE CO-CREATION AND CUSTOMER SATISFACTION IN AVIATION INDUSTRY IN NIGERIA
}

\author{
WORLU, STANLEY DIKE \\ Department of Marketing, University of Port Harcourt, Port Harcourt \\ Email: hachikaruikachi@gmail.com \\ EZIRIM, ALOY CHINEDU \\ Department of Marketing, University of Port Harcourt, Port Harcourt \\ Email:ezirimac@gmail.com
}

\begin{abstract}
The study examined the relationship between value co-creation and customer satisfaction in Aviation Industry in Nigeria. The theoretical framework covered DART theory that explained how customer satisfaction will be improved using value co-creation. A sample size of 320 was determined from a population of 1600 respondents using Taro Yamane's sampling technique. Data were collected through questionnaire. 320 copies of questionnaire were distributed to the respondents out of which 303 copies were found useful for data analysis. The data were analyzed using Spearman's Rank Order Correlation Coefficient Statistic which was facilitated through the application of Statistical Package for Social Science (SPSS Version 23.0). The findings showed a significant relationship between value co-creation and customer satisfaction in Aviation Industry in Nigeria. Based on the findings, the study concluded that value co-creation affects customer satisfaction in Aviation Industry in Nigeria. Hence, the study recommended that management should place more emphases on increasing customers' satisfaction through value co-creation. They should build customers' experience through personal interaction, make strategic involvement of customers and organization in guiding the activities of the business and build an effective engagement platform with the aim to maintain personal touch across all customers to increase customer loyalty and emotive commitment which are core measures of customer satisfaction in Aviation Industry in Nigeria
\end{abstract}

Keywords: Value Co-creation, Personal Interaction, Engagement Platform, Customer Loyalty, Emotive commitment, Aviation Industry 


\section{Introduction}

Aviation Industry is an important transportation industry or sector in Nigeria. The industry promotes economic development and contributes greatly to the success of transportation system in Nigeria. The Industry for instance employed workers and helps in reducing the level of employment in the country. When an industry like Aviation Industry have in mind to satisfy its customers always, such industry can withstand turbulent business challenges and will gain competitive advantage over others (Vilare et al., 2001). According to Kotler and Keller (2009), when customers are satisfied, they develop brand loyalty, refer other customers to patronize the brand and services. With respect to the Aviation Industry, the satisfied customer will encourage others to travel with the Airline which they derived satisfaction. As this referring process continues, the customers will develop customer loyalty and emotive commitment.

The vital area which Aviation Industry has not identify as the basic mechanism for satisfying customers lies in adopting value co-creation concept (Nirmali, Tajid \& Azam, 2001; Ramaswamy \& Ozcam, 2014). In fact, many scholars or authors have also not extensively study value co-creation concept as a determinant for customer satisfaction. When the study of value co-creation is approached as a major means of satisfying customers, the Aviation Industry and other business organizations will see the need to invite customers in creation of values for goods and services. Still on value co-creation, personal Interaction is developed as customers becomes friendly with the organization. They also develop trust and respect for each other; they share their views and experiences. What comes out due to personal interaction between both parties will pave way for the success of value co-creation since the firm (Airline) will engage such a customer in value co-creation initiative (Lee et al., 2012). Another important dimension is engagement platform which serves as a market or channel where customers and a firm meet to decide on how the nature and quality of products and services should be produced to meet customers' needs (Srinivasan, \& Hanssens, 2009).

It is quite obvious that many authors and researchers have conducted studies on value cocreation over the years (Spreng, Harrell \& Mackoy, 1995; Payne, Storbacka \& Frow, 2008; Ramaswamy \& Goüllart; 2010) but most of the researchers focused on manufacturing firms with no regards to the Aviation Industry which is a critical sector that needs value cocreation on services provided. Additionally, those researchers and their studies were carried out in foreign environment of which their culture may be different from firms in the domestic environment like Nigeria. Hence, the present is carried out to examine the relationship between value co-creation in Aviation Industry in Nigeria with the aim to fill this knowledge gap.

\section{Statement of the Problem}

Aviation industry has made a significant contribution to Nigeria's and the world's economic and tourism development. As a result of the rapid entry and exit of goods and services, the Nigerian aviation industry generates more revenue and contributes to the economy, ensures promotion and improvement of people's quality of life and living standards across the country. However, it appears that the performance of Nigeria's aviation industry is deteriorating. This is evidenced in frequent complaints by customers with respect to quality of services delivery Organization that involved customers in value co-creation increases their level of satisfaction but reverse is the case with Aviation Industry in Nigeria. The 
Industry failed in this aspect and failure to make available and necessary services inevitably lead to customer dissatisfaction. The dissatisfaction of customers was observed in frequent complaints by customers about poor service delivery, lack of provisions of adequate security and safety measures. The use of obsolete equipments and poor infrastructure is another problem. The use of second handed transport Airplanes or Aircrafts have resulted in disaster or crashed and takes many lives (e.g. Sosoliso Airline crashed). Other Airlines are no longer in operations (e.g. Changangi, ADC, Okada Airlines etc).

Poor development of skills and manpower unavailability including high cost of booking tickets were also observed. Additionally, it was noted that the Industry exhibits poor maintenance culture which is evidenced in poor lighting on Run-ways; couple with internet service failures; poor Car Hiring services and its environment; poor pharmacy/First Aid facilities and services; poor convenience facilities and poor customers and employee relationships. All of these are problems causing customers dissatisfaction in Aviation industry in Nigeria. Similar problems were identified in the foreign environment by Payne et al. (2008) that lack of value co-creation affects organizational growth. However, in Aviation industry in Nigeria, it was observed that these problems stemmed from lack of involving customers in value co-creation practice.

The manifestations of customer dissatisfaction have affected the Aviation Industry in terms of growth, sales volume, profitability, customer relationship development and technological advancement. Hence, seen Aviation Industry as an important sector for economic viability in Nigeria, any encroachment on its performance will exert a strong negative result on the economy as well. This has necessitated the present study to examine the relationship between value co-creation and customer satisfaction in Aviation Industry in Nigeria to provide solutions to this problem.

\section{Aim and Objective of the Study}

The aim of this study was to examine the relationship between value co-creation and customer satisfaction in Aviation Industry in Nigeria, while the study objectives are:

1. Evaluate the relationship between personal interaction and customer satisfaction in Aviation Industry in Nigeria.

2. Find out the relationship between engagement platform and customer satisfaction in Aviation Industry in Nigeria.

\section{Research Questions}

The following research questions guided the study

1. How does personal interaction relate to customer loyalty in Aviation Industry in Nigeria?

2. How does personal interaction relate to emotive commitment in Aviation Industry in Nigeria?

3. What is the relationship between engagement platform and customer loyalty in Aviation Industry in Nigeria?

4. In what ways does engagement platform relates to emotive commitment in Aviation Industry in Nigeria? 


\section{Conceptual Framework}

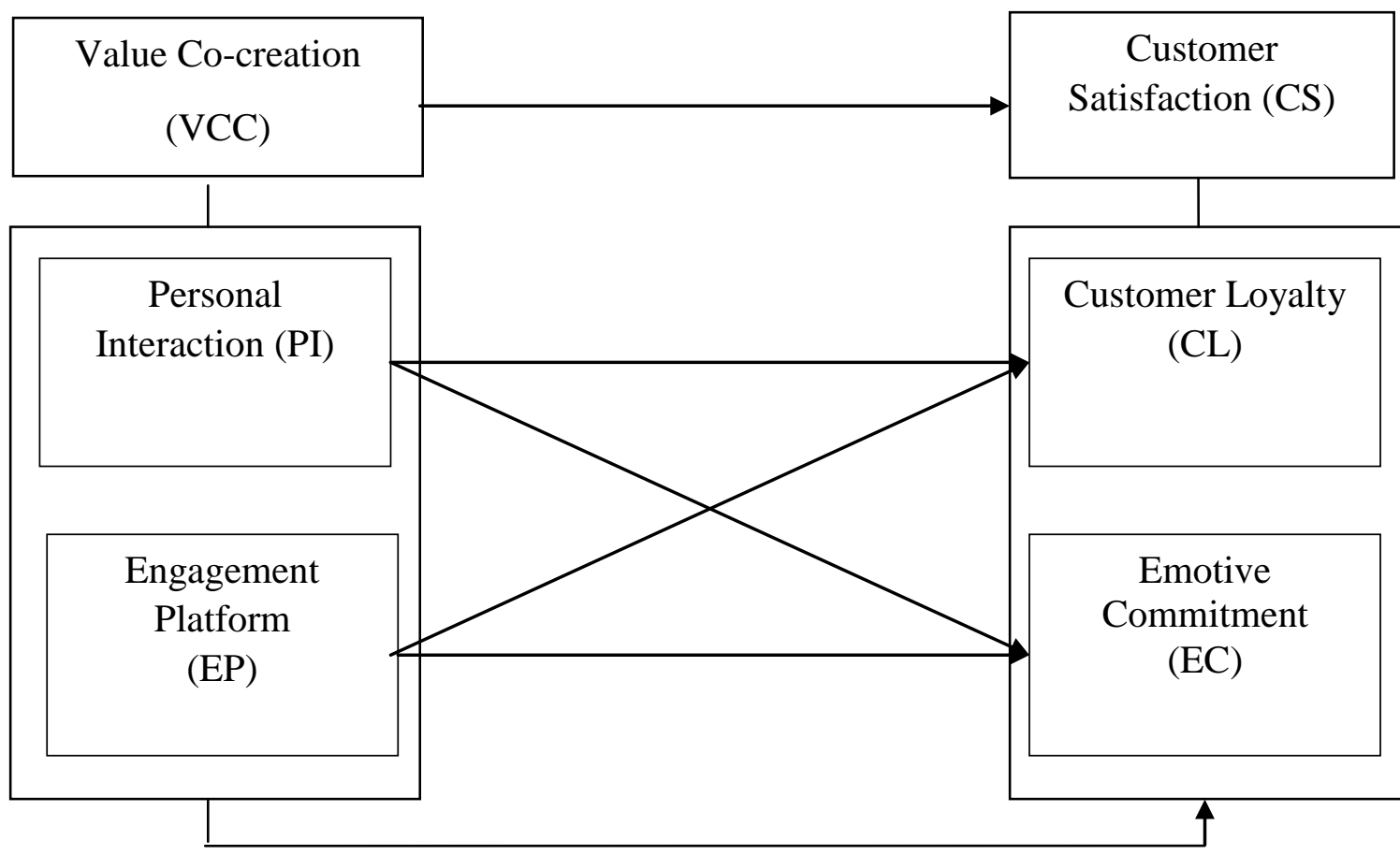

Figure 1.Conceptual Framework of the Relationship between value co-creation and Customer Satisfaction

Source: Dimensions of Value Co-Creation (Spreng, Harrell \& Mackoy, 1995; Nirmali, et al., 2001; Ramaswamy Ozcan, 2014). Measures of customer retention (Gronroos, 2000).

\section{Research Hypotheses}

The following research hypotheses were formed to guide the study:

Ho: : There is no significant relationship between personal interaction and customer loyalty in Aviation Industry in Nigeria.

Ho$_{2}$ : There is no significant relationship between personal interaction and emotive commitment in Aviation Industry in Nigeria.

Ho3: There is no significant relationship between engagement platform and customer loyalty in Aviation Industry in Nigeria.

Ho4: There is no significant relationship between engagement platform and emotive commitment in Aviation Industry in Nigeria.

\section{Significance of the Study}

The findings from the study will add meaning to the customers, future researchers, managers, stakeholders and captains of industries including other business organizations. Aviation Industry will know the need for value co-creation and embrace it as a strategy during planning or decision making process on how to create value of products or services that will satisfy customers. The study will also help customers to see the reason why they must be involved in creating the value of services that will satisfy them. Future researchers 
will see the research findings as meaningful for future literature review. Secondly, the gap found will be useful in carrying out further research in the area of concerns.

The study was domiciled in relationship marketing and consumer behaviour because value co-creation emphasizes on establishing cordial relationship with customers with the aim of improving customers' loyalty. The geographical scope of the study covered all Airports in Nigeria. The unit/level of analysis was ascertained from the individual level because it considered only internal and external customers of the Aviation Industry. Additionally, these categories of respondents are direct consumers of Aviation services of which their level of satisfaction might dictate the success of the Aviation Industry.

\section{LITERATURE REVIEW}

\section{Theoretical Framework}

DART theory was adopted in this research because it promotes value co- creation practice. DART theory was propounded and developed by Prahalad \& Ramaswamy (2004) which spoke against the previous concept of traditional marketing model. Previously firms provide goods and services alone without involving customers. Customers during that time became passive recipients to the product. Since customers are those who make use of the goods and services there is need to involve them in value co-creation activities. DART theory supported value co-creation activities to involve other parties concerned.

Customers and service providers bilaterally create value of goods and services that satisfies the needs and wants of the customers (Troccoli, 2010; Fisher \& Smith, 2011; Troccoli \& Aitaf, 2012). DART as an acronym is expressed as follows; the letter ' $D$ ' means 'Dialogue' which has to do with Interactions for decision implementation. Letter ' $A$ ' denotes 'Access' which involves participation or involvement. Furthermore, letter ' $R$ ' means Risk which shows that trust, tolerance, loyalty, commitment are necessary. Finally, the letter ' $\mathrm{T}$; denotes transparency). DART theory encourages value co-creation that is transparent in terms of feedback, friendship, reciprocation, experience and knowledge sharing (Ramaswamy \& Prahalad, 2004). When customers and firm meet to make decision on service provisions, it leads them to trust each other and to be transparent because both parties will share experience with each other clearly.

Prahalad and Ramaswamy (2004) explained that when the customers and the firm engage in personal interaction, vital information is exchanged which might be useful to stand against the competitive business environment. Through dialogue both parties will exchange experiences about the goods and services they want to provide to the customers. Dialogue or interactions flow in different dimensions between customers and workers in the organization. Information through this medium leads to searching for new discoveries and innovations. Customer interaction with firm might be on improving existing services or new innovation of services that which must be discussed as well such services can be created and be delivered effectively (Ballantyne \& Varey, 2006).

\section{Empirical Review}

Neghina, Caniels, Bloemea and VanBirgelon (2014) proposed three dimensions of value cocreation in studying relationship management concept. The three dimensions are: connection to customers, trust of customers, and commitment of customers. The authors 
used mix method to collect data and examine how customer relationship management affects the performance of firms. The study recommended that management must manage their relationship with the customers through these dimensions.

Other researchers have conducted studies on value co-creation Mc-Coll Kennedy, Vargo, Dagger, Sweeny and Van Kasteren (2012) divided value co-creation into eight dimensions. It means there are different types of value co-creation. Every business organization has its own goods and services and also has its own customer's even non-business organization. The eight different types identified in value co-creation are connecting/ co-production, cooperating, collaborating, information, and co-learning which affect firm's target or goal attainments.

Nirmali et al. (2001) conducted a research on value co-creation and firm's performance. They used environment, engagement platform as dimensions of value co-creation and as strategies or techniques to achieve success in business operation. Sales growth and profit margin were used as measures of firm's performance. The study sampled 27 service firms in the industry which was obtained by using convenience sampling method or technique. They adopted survey research design and employed Spearman's Rank Correlation Coefficient statistic in testing the hypotheses. They found a positive relationship between value cocreation and firm's performance. The implication is that firm that makes use of customer involvement, engagement platform and other dimensions for value co-creation improves firm's performance. Such firm will end up satisfying customers which in turn will lead to growth and profit maximization for the organization.

From the empirical review it is obvious that many studies have not been conducted on value co-creation and customer satisfaction in Nigeria especially in aviation industry. This might stemmed from unawareness of value co-creation and how it works. Hence, the present study tends to fill this gap in literature as it examines the relationship between value co-creation and customer satisfaction in aviation industry in Nigeria.

\section{Value Co-Creation}

Value reflects the sum total of perceived tangible and intangible benefits and costs to customers (Kotler \& Keller, 2009), while, value co-creation is seen as a process that involves customers and firm to come together and assess the value of goods and services before creation which will be of common interest and yield benefits to both parties (Prahalad \& Ramaswamy, 2004). It makes both parties to know what each other want or need more especially, for the customers who are the consumers of the goods and services. Through this process, the organization will know what customers need and provide it accordingly. Prahalad and Ramaswamy (2004) added that buyers choose among different offerings as they perceived to deliver the value. The extent to which a firm gets involved in co-creation and improvements in firm's growth and profitability has been widely discussed in literature (Prahalad \& Ramaswamy, 2004; Prahalad \& Krishnan, 2008; Nicolajsen \& Scupola, 2011; Macdonald et al., 2011; Lusch \& Webster, 2011).

According to Chathotha, Altinay, Harrington, Okumus and Chane (2012), value co-creation need a good sense of participation and only intelligent actors can make it successful. Roser, DeFillippi and Samson (2013) argued that all co-creation approaches have two common qualities: the widening of organizational boundaries and the involvement of co-creators. They concluded that firm's performance usually use a pool of ideas and strategies and has 
its own unique approach in co-creation which is specific in its aim to increase the productivity. Value co-creation involves interactive dialogue between a firm and a group of consumers (Russo-Spena et al., 2011), that can vary in depth of interaction, with the goal of jointly producing the value of the offerings to both the firms and the consumers (Maklan et al., 2008). Groth (2005) noted that co-creators include firm and customers who developed their willingness to apply their competencies in providing services for the benefit of others and themselves. Not only can these clients co-produce but also co-consume.

\section{Customer Satisfaction}

The aim of every organization is to survive and to achieve this they must ensure that their customers are satisfied. Satisfying the customers will generally increase sales to a high level. Organizations produced goods and services for customers to make purchase. Some are doing so without having in mind what is exactly needed by the customers thereby ending up dissatisfying their customers. While others who are trying to satisfy their customers continue in business operations. So, the question is; what are the manifestations of customer satisfaction? Or what can be used in measuring customer satisfaction? There are things we see or observe that take place in the behaviours and actions by customers which shows that they are satisfied. Some of the indicators include repeat purchase (Stone, 2000); customer loyalty (Kincaid, 2003); trust (Bansal, Irving \& Taylor, 2004) positive word-of-mouth and emotive commitment (Harrison, 2001; Lee \& Thorson, 2008). The organization will notice these in customers' behaviour towards a particular brand or services (Vilares et al., 2001). The services provided by an organization (Airline) are compared to initial expectation and what is derived from that product or services consumed denotes satisfaction or dissatisfaction. This simply means that customers are satisfied or dissatisfied after using the products and services. If satisfied, the customer will form positive emotional commitment, or if not satisfied, the customer will look for alternative (Clu, 2002).

When customers are satisfied they keep buying and telling people about the goodness of the products and services. Customer expectation could be the sum of customer wants and needs to produce loyalty (Stone, 2000). Researchers have found that customer expectations lead to loyalty, trust, a positive word of mouth (Lees \&Thorson, 2008; Kincard, 2003; Bansal, Irving \& Taylor, 2004) and emotive commitment.

\section{Customer Loyalty}

Customers are group of persons or individuals that consume or buy the goods or services of the firm (Kolter \& Keller, 2009). Customers are the passengers of the Airline and those who engaged in buying the products or services of the Airline. Customers are also people in the market trying to buy products or services. In short they are the core drivers of firm's success. While loyalty is a behavior which the customers may exhibit to brands, services, stores, or product categories, customer loyalty is a key variable that explains why customers are committed to a product or service of a firm (Kolter \& Keller, 2009).

Customer loyalty is observed when customer keeps buying a particular product or service each time and among other similar products or services. The customers can only repeat purchases after consumption of the same product or service that gives them satisfaction. Customers who repurchase the same products or services show that they have developed interest over the products or services (Dong \& Zhou, 2006). When a customer developed a 
buying behavior or flying with a particular Aircraft, it means that such customer has developed a passion for flying with the Airline which denotes customer loyalty. Thus, value co-creation of products and services will improve customer loyalty in aviation industry in Nigeria.

\section{Emotive Commitment}

Customer emotive commitment depends on how the customer sees the firm and its products or services. When a customer develops emotive commitment it means that the customer is attached to what the firm offered (Guren, summer \& Acito, 2002). Emotional commitment is the force or power that drives customers to start appreciating or developing passion for the service of the firm. If the customers have trust on the services delivered by the firm such customer will develop emotive commitment (Bansal, Irving \& Taylor, 2004). When a customer develops emotive commitment it becomes difficult to change the customer's mind. Such customer will insist to travel with the Airline committed to in years past. The customer will insist not to change because such customer has never been disappointed by the previous firm. The customer develops emotive commitment because he feels deeply in his mind that the Airline is the best transport system (Fullerten, 2005). Therefore value cocreation will improve emotive commitment in aviation industry in Nigeria.

\section{Value Co-Creation and Customer Satisfaction}

In value co- creation process, the Industry and customers have their individual roles to play (Gummession et al., 2008, 2009). As the Airline is selling its tickets, the customer or passengers are booking. As the Airline is sending out their Air tickets the customers or passengers are receiving it. The Airline is sending out value while customers are receiving it. In marketing literature, this type of value transaction between the service provider (Airline) and customers is referred to as; 'value -in- exchange (Cova \& Dalli, 2009). The value referring here comprises of quality, price, durability, size and reliability which are embedded in the products or services by the Industry with its customers Cova \& Dalli, 2009). However, when Aviation Industry consider themselves only in providing values without carrying customers along or without considering customers opinion, then, the customer will definitely not be satisfied. In this instance, the Aviation industry needs to create value in what customers want and need, to satisfy them.

For effective value co-creation practice there must be conducive atmosphere, a comfortable platform to facilitate the process. The platform will also be conclusive in that there must be equal treatment and customers' opinions be respected as part of key decision makers. As customers are treated this way, they will see themselves as partial employees of the Airline and will begin to use words of mouth to persuade other potential customers to patronize the Airline. They will also refer other potential customers to purchase goods and services to the firm. Such customer's behavior will change as they develop loyal attitude either to the firm (Airline) or for products and services offered by the Airline. Thus, value co- creation is complete or successful when the opinion or the suggestion made by customers is implemented (Grand 2002).

\section{METHODOLOGY}

\section{Research Design}

This study adopted cross-sectional research design as it is a quasi-experimental survey 
research. The cross-sectional research design is suitable since the respondents were not under the control of the researcher. The cross-sectional research design was applied because the study dealt with more organizations at the same time. Furthermore, the cross-sectional research design was appropriate because it was a descriptive research. Also, the crosssectional research design assisted in providing a deep analysis of a selected number of variables involving the analysis of interrelationships among several variables (Okwandu, 2006).

\section{Population}

The study target population comprises of customers (internal/external customers) in Aviation Industry in Nigeria. The available record indicates eight (8) operational Airline services in Aviation industry in Nigeria within the research period. These Airlines have their branches in Port Harcourt International Airport (Industry Report, 2019). However, the study examined 1600 respondents comprised of internal and external customers in the eight (8) operational Airline Services. This accessible population of 1600 respondents was determine from the human resource department of each Airline using purposive or convenient sampling technique.

\section{Sample size and Sampling Techniques}

The study adopted Taro Yamane's sampling technique (Yamane, 1967). This technique helps in determining the sample size of 320 customers from huge population of 1600 respondents. Furthermore, Bowley (1964)'s technique was applied for the purpose of adequate distribution of questionnaire.

Instrument design: The research instrument was entitled "Value Co-Creation and Customer Satisfaction Questionnaire" (VCCCSQ). The instrument (questionnaire) consisted of eighteen (18) items which sought the views of respondents on value co-creation and customer satisfaction in the Aviation Industry in Nigeria. The instruments were divided into two sections ' $A$ ' and ' $B$ '. The first 'section A' contained items on demographic variables, while 'Section B' contained items describing all the variables (dimensions of value cocreation and measures of customer satisfaction. 320 copies of the questionnaire were administered directly to respondents and assisted by two graduate assistants. Instructions guiding the filling of the questionnaire were provided and the questionnaire were filled and retrieved in a short time. Using questionnaire in collecting the data was helpful because it allowed the respondents to have enough time to ponder over the question before answering. The demographic data were obtained directly from the customers on age of respondents, educational qualifications, experience, and frequency of travel with the Aviation Industry, while the study variables were gathered from respondents through questionnaire which captured customers' opinion expressed to the items on the study variables. The secondary data were obtained from marketing literature, management literature and materials from other related field of study. Precisely, the sources include; journals, text books and internet.

\section{Operational Measurement of Variables}

The predictor variable is value co-creation and its dimensions are personal interaction and engagement platform. Five item statements were used to measure personal interaction on a Likert 5-point scale. Four item statements were used to measure engagement platform on a Likert 5-point scale. For the variables a score of 1 was assigned to Neutral; $2=$ strongly disagree; $3=$ disagree; $4=$ agree; and $5=$ strongly agree. The criterion variable is customer 
satisfaction and its measures include; customer loyalty and emotive commitment. For customer loyalty four item statements were used to measure this variable on a Likert 5-point scale. Emotive commitment was measured using five item statements on a Likert 5-point scale. A score of 1 was assigned to Neutral; $2=$ strongly disagree; $3=$ disagree; $4=$ agree; and $5=$ strongly agree.

\section{Validity and Reliability of Instrument}

The study adopted face and content validity. The instrument was subjected to scrutiny by supervisors and other experts and found that the item statements properly represented the variables measured (face validity). While the content validity was ascertained using multiple items that covered all aspect of the variables (Spector, 2008). This shows that the domains of all variables were covered with items necessary for the measurement.

Reliability of Instrument: The study applied Cronbach Alpha reliability test to ascertain the reliability of the instruments and achieved reliability score of 0.7 or above which was the benchmark for reliability acceptance (Cronbach, 1951). The reliability test computation was performed through the application of SPSS version 23.0. Thus, the following results were obtained. Personal interaction scored 0.976; $n=5$. Engagement platform scored 0.808; $\mathrm{n}=4$. Customer loyalty scored $0.779 ; \mathrm{n}=5$. Emotive commitment scored $0.870 ; n=5$. Thus, from the analyses, the results showed a reliability score above 0.7 . This shows that the study used a reliable instrument

\section{Methods of Data Analysis}

Two types of data analyses were employed. These are the descriptive and the inferential data analyses (Okwandu, 2006). The descriptive data analysis include univariate analyses, while, the inferential data analyses include; bivariate and multivariate analyses. We analyzed our data by describing and summarizing them (descriptive data analysis). Graphs were used in presenting data while their values were expressed in percentage. The demographic variables and research questions were analyzed using descriptive statistic, while the hypotheses were tested using non-parametric statistical test in making inferential decisions. This was achieved by applying Spearman's Rank Order Correlation Coefficient statistic which is a non-parametric test statistic.

\section{RESULTS AND DISCUSSION}

A total of $320(100 \%)$ copies of questionnaire were administered to the eight (8) Aviation Firms. The obtained useful copies were 303(94.7\%), while the abandoned copies were 17(5.3\%). This result indicates that huge number of the respondents participated in providing data for this study. This shows a success in questionnaire administrations. Hence, the study proceeded to analyze the demographic data of the respondents. 


\section{Demographic (Descriptive) Data Analysis}

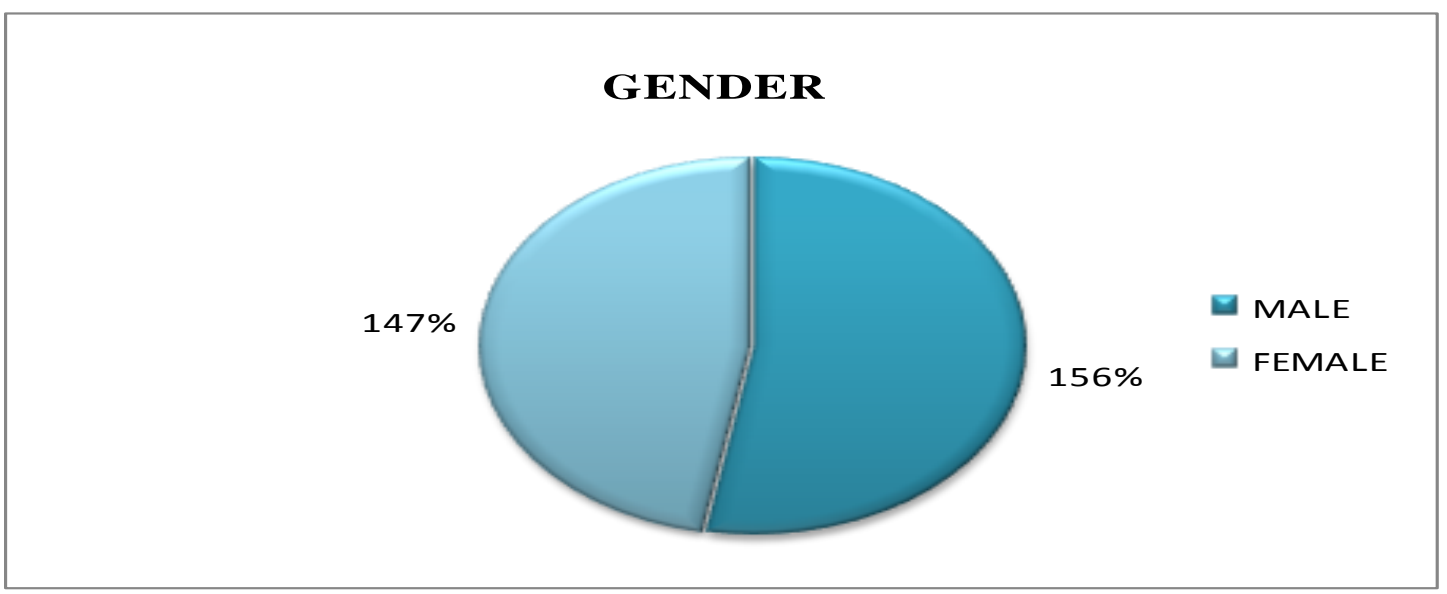

Fig. 1 Gender of Respondents. Source: Excel Output (2021)

The pie chart of figure 1 above shows the percentage rate of on gender. The result shows that $156 \%$ were male while $147 \%$ were female implying that high percent of male participated in generating data for the study.

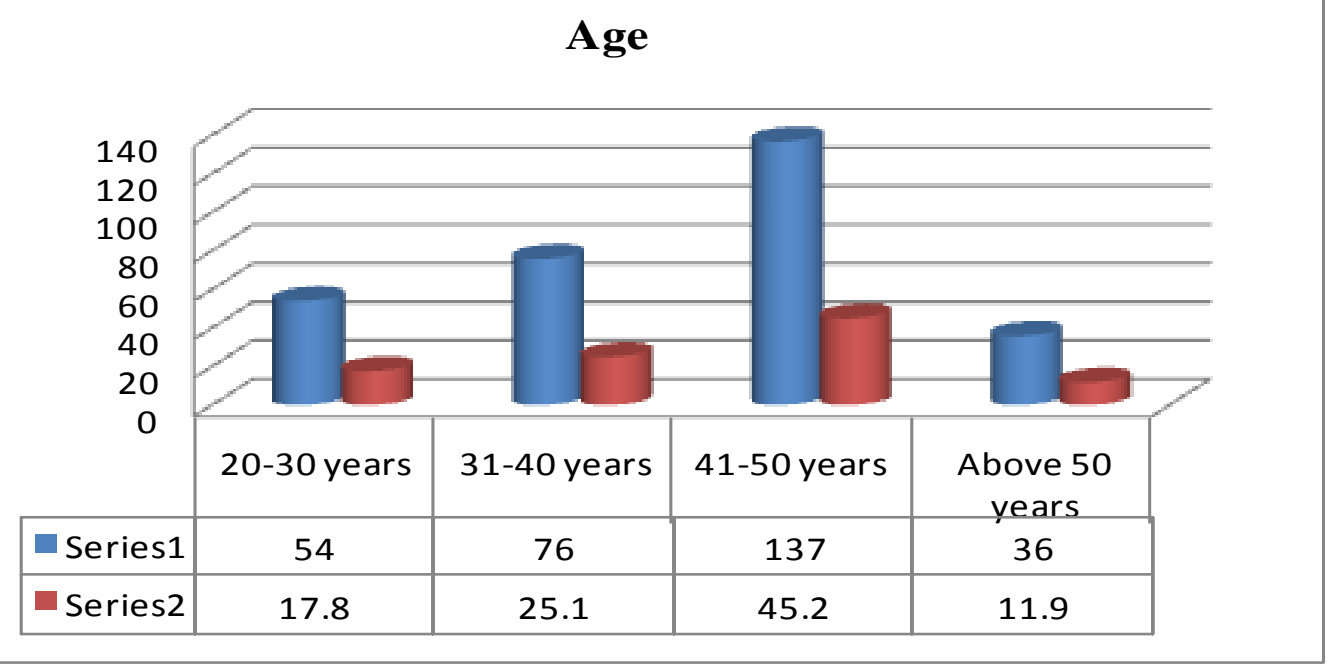

Fig. 2: Age of Respondents. Source: Excel Output (2021).

The column chart of figure 2, represent the entire age bracket of respondents who participated in generating demographic data for the study. 17.8\% were between 20-30 years, $25.1 \%$ were between $31-40$ years, while $45.2 \%$ were between $41-50$ years and only $11.9 \%$ were above 50 years. The highest percentage and frequency occurred at the age between 3140 years. 


\section{Educational Qualification}

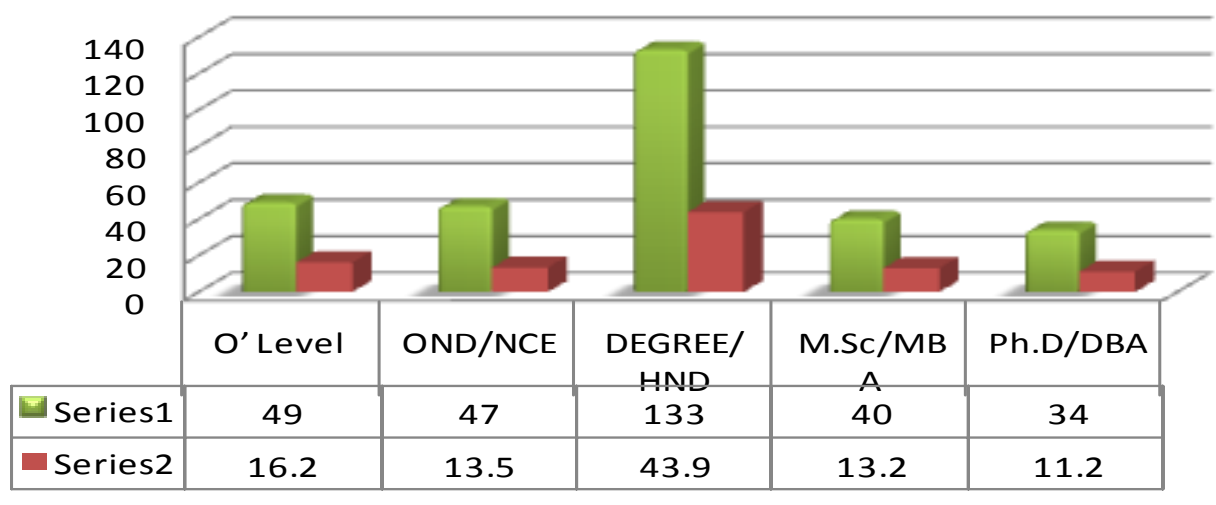

Fig. 3: Educational Qualifications of Respondents. Source: Excel Output (2021)

Figure 3 above displayed the column chart on the educational qualifications of the respondents. The tallest column represents the highest number of customers that have first degree $(43.9 \%)$ followed by O' Level (16.2\%). While, OND/NCE scored $13.5 \%$ and M.Sc/MBA scored 13.2 left Ph.D/DBA with $11.2 \%$. Thus, most frequency occurrence was Degree/HND holders.

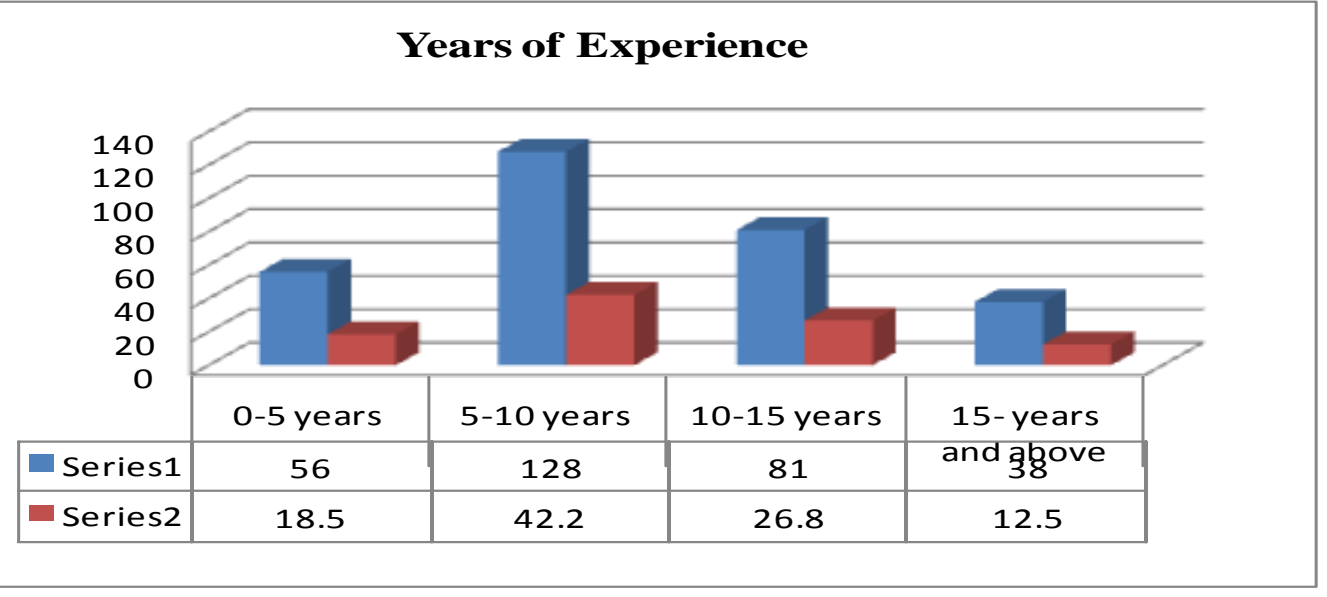

Fig. 4: Years of Experience: Source: Excel Output (2020).

The column chart of figure 4 shows the percentage of years of experience of the customers. In this case, $18.5 \%$ were between $0-5$ years; $42.2 \%$ were between $5-10$ years while $26.8 \%$ were those between 10-15 years, and $12.5 \%$ indicated above 15 years. Thus, majority responded between 5-10 years. 


\section{Categories of Customers}

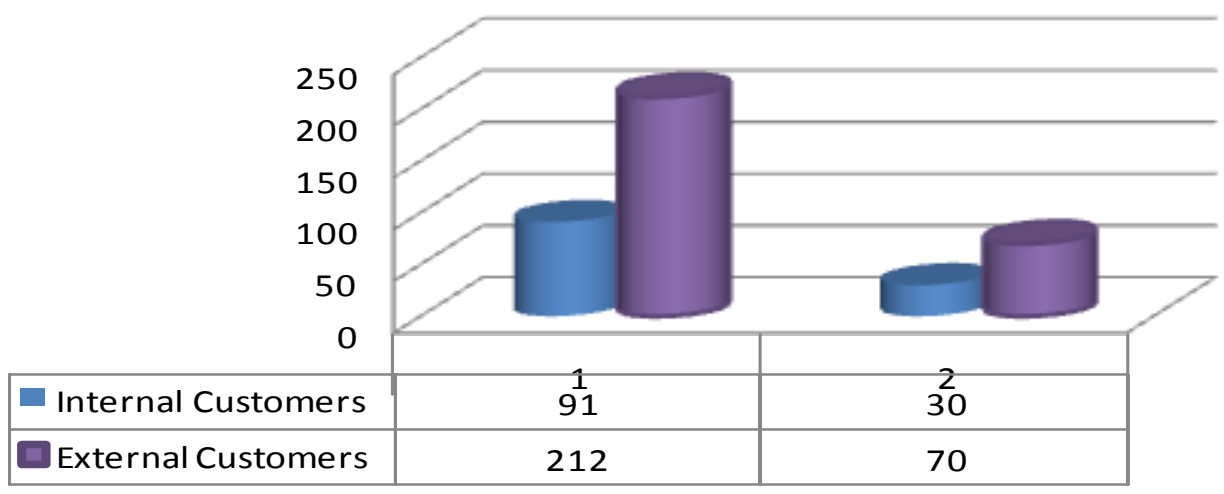

Fig. 5. Categories of Customers. Source: Excel Output (2020).

The result of figure 5 shows that most were external customers. In the Aviation Industry there are two categories of customers who patronize the services of the industry. The external customers were those who only book online or purchase tickets and travel out without setting up a business internally with the Aviation Industry. While the internal customers are those who set up a business or businesses with the Aviation Industry, or work with the industry and provide services to the industry regularly.

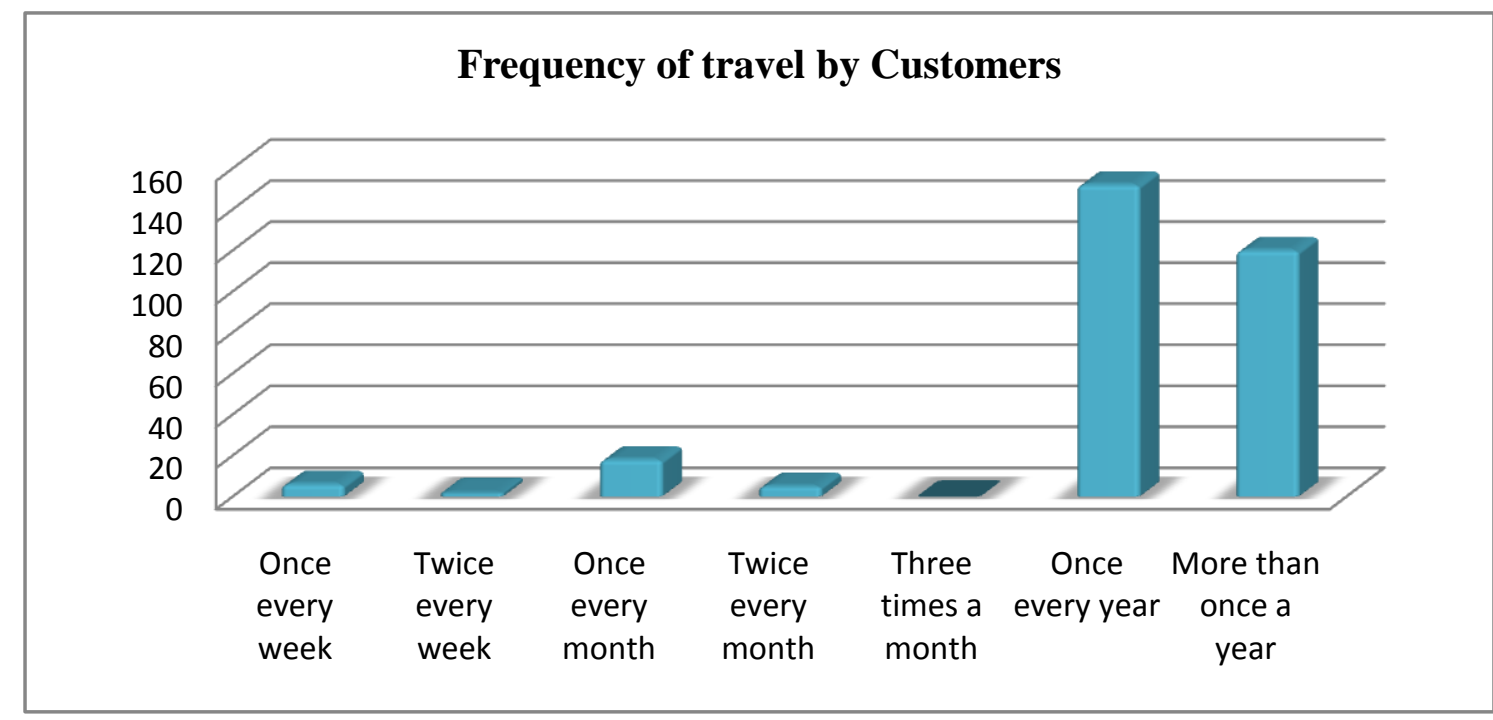

Fig. 6. Frequency of Travel by the Customers. Source: Excel Output (2021).

The column chart of figure 6 shows the percentage of responses to frequencies of travel by the customers. In this case, the highest traveling frequency occurred at once every year. 


\section{Level}

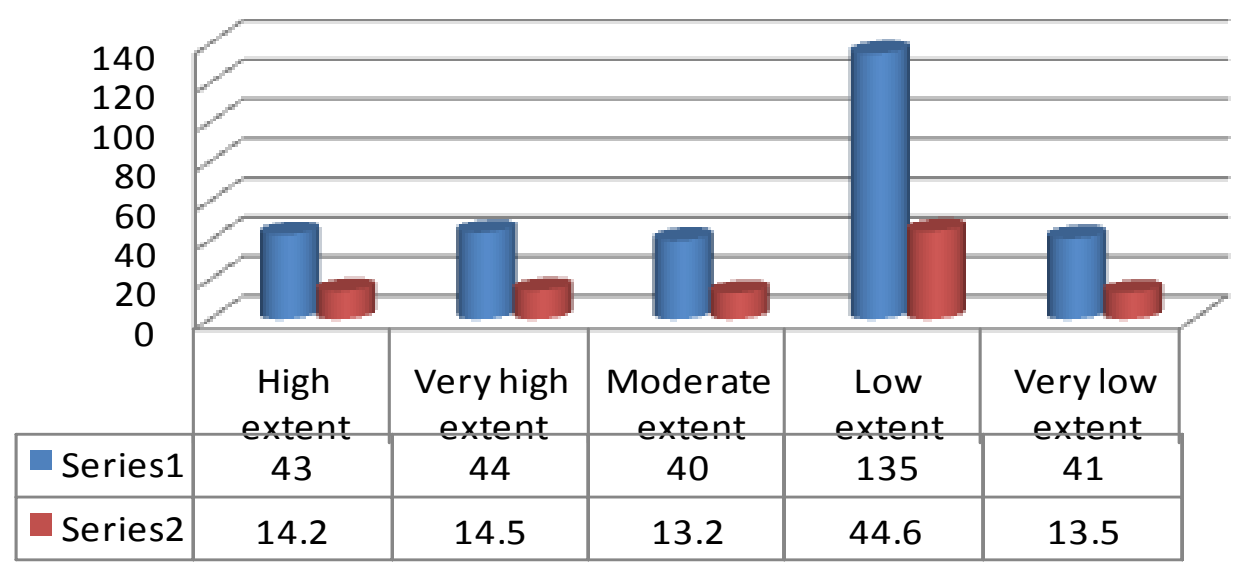

Fig.7. Frequency of level of extent. Source: Excel Output (2021).

Figure 7 shows the extent to which customers suggest or contribute to quality of their Airline services. The highest response rate on the cylinder chart is $135(44.6 \%)$ which shows a low extent and thus, majority of the respondents indicated low extent to which customers suggest or contribute to quality of their Airline services.

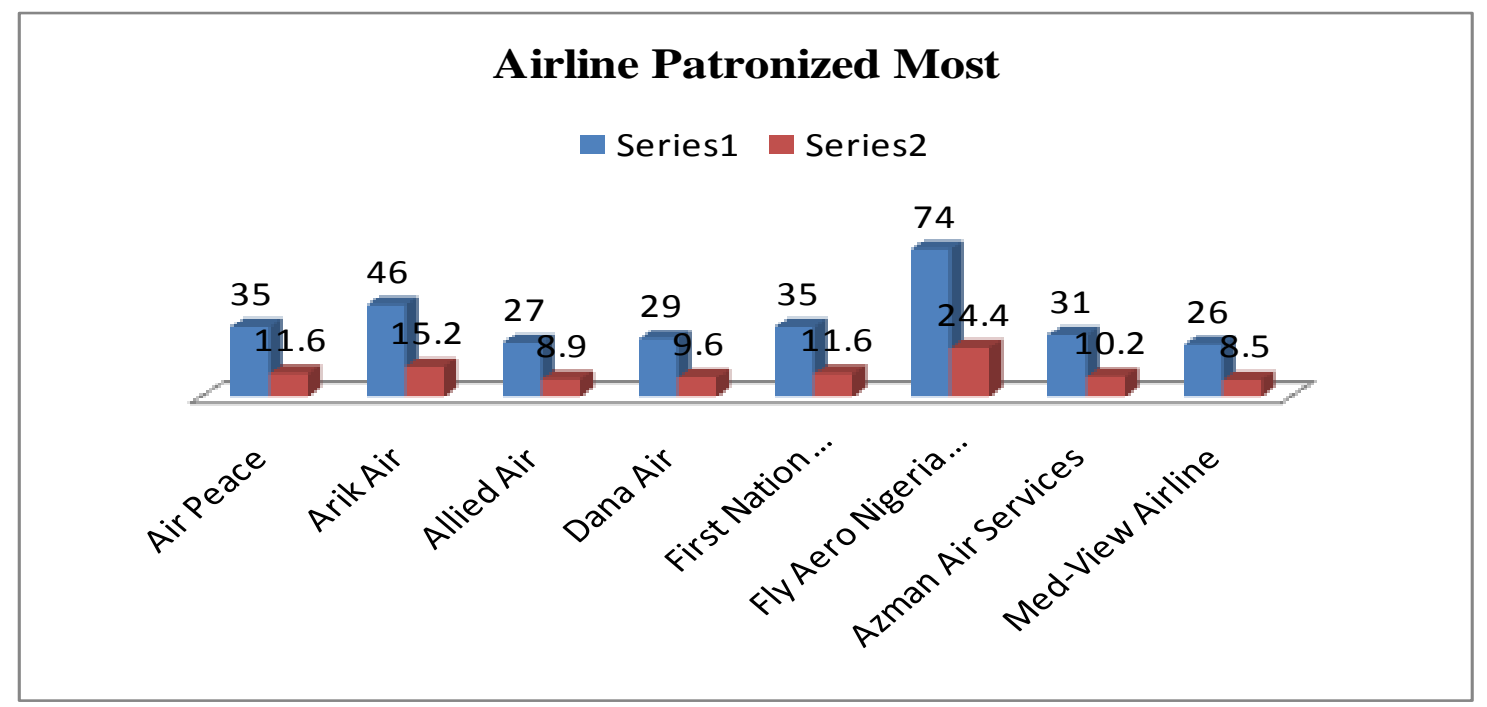

Figure 8: Airline patronized most excel output 2021

From figure 8 the highest column chart results is Fly Aero Nigeria Limited. Hence, it is observed that majority of the customers travel by Fly Aero Nigeria Limited followed by Arik Air and others.

\subsection{Hypotheses Testing}

The bivariate analysis centered on testing the null hypotheses on the relationship between dimensions of value co-creation and measures of customer satisfaction. The decision depends on the level of correlation result obtained either to reject or accept the null 
hypotheses. The level of significance is given at 0.05 . In this regard, when the probability value (p-value) is less than 0.05 level of significance the study rejected the null hypothesis. However, when the probability value ( $\mathrm{p}$-value) is higher than 0.05 level of significance, the study accepted the null hypotheses.

Test of Hypothesis (1)

This hypothesis was tested to provide answer to research question 1 on the issue of personal interaction and how it relates to customer loyalty in Aviation Industry in Nigeria.

$\mathbf{H}_{\mathbf{0 1}}$ : There is no significant relationship between personal interaction and customer loyalty in Aviation Industry in Nigeria.

Table 1: Correlation between Personal Interaction and Customer Loyalty Correlations

\begin{tabular}{|lll|r|r|}
\hline & & \multicolumn{1}{c|}{$\begin{array}{c}\text { Personal } \\
\text { interaction }\end{array}$} & \multicolumn{1}{c|}{$\begin{array}{c}\text { Customer } \\
\text { Loyalty }\end{array}$} \\
\hline Spearman's rho & Personal interaction & Correlation Coefficient & 1.000 & $.768^{\prime \prime}$ \\
& & Sig. (2-tailed) &. & .000 \\
& $\mathrm{~N}$ & 303 & 303 \\
\cline { 2 - 5 } & Customer Loyalty & Correlation Coefficient & $.768^{\text {n. }}$ & 1.000 \\
& & Sig. (2-tailed) & .000 &. \\
& $\mathrm{~N}$ & 303 & 303 \\
\hline
\end{tabular}

${ }^{\star \star}$. Correlation is significant at the 0.05 level (2-tailed).

The result on table 1 presented the relationship between personal interaction and customer loyalty. The correlation occurred at 0.768 , when the p-value is less than 0.05

\section{Test of Hypotheses (2)}

With respect to hypothesis 2 , the research question is; what is the relationship between personal interaction and emotive commitment in Aviation Industry in Nigeria?

$\mathbf{H}_{\mathbf{0 2}}$ : There is no significant relationship between personal interaction and emotive commitment in Aviation Industry in Nigeria.

Table 2: Correlation between Personal Interaction and Emotive commitment Correlations

\begin{tabular}{|lll|r|r|}
\hline & & \multicolumn{1}{c|}{$\begin{array}{c}\text { Personal } \\
\text { interaction }\end{array}$} & $\begin{array}{c}\text { Emotive } \\
\text { commitment }\end{array}$ \\
\hline Spearman's rho & Personal interaction & Correlation Coefficient & 1.000 & .611 \\
& Sig. (2-tailed) &. & .000 \\
& $\mathrm{~N}$ & 303 & 303 \\
\cline { 2 - 5 } & Emotive commitment & Correlation Coefficient & $.611^{\star *}$ & 1.000 \\
& Sig. (2-tailed) & .000 &. \\
& $\mathrm{~N}$ & 303 & 303 \\
\hline
\end{tabular}

${ }^{\star *}$. Correlation is significant at the 0.05 level (2-tailed).

The result on table 2 indicates that personal interaction correlates with emotive commitment at 0.611 when $p$-value is less than 0.05 level of significance $((p(0.000)<0.05))$. Hence, null hypothesis was rejected because a positive and significant relationship exists between personal interaction and emotive commitment. 


\section{Test of Hypotheses (3)}

Hypothesis 3 was tested to provide answer to research question 3 on the issue of engagement platform that will bring customer loyalty. How does engagement platform relate to customer loyalty in Aviation Industry in Nigeria?

$\mathbf{H}_{\mathbf{0 3}}$ : There is no significant relationship between engagement platform and customer loyalty in Aviation Industry in Nigeria.

Table 3: Correlation between Engagement Platform and Customer Loyalty Correlations

\begin{tabular}{|c|c|c|c|c|}
\hline & & & $\begin{array}{l}\text { Engagement } \\
\text { Platform }\end{array}$ & $\begin{array}{l}\text { Customer } \\
\text { Loyalty }\end{array}$ \\
\hline \multirow[t]{2}{*}{ Spearman's rho } & Engagement Platform & $\begin{array}{l}\text { Correlation Coefficient } \\
\text { Sig. (2-tailed) } \\
\mathrm{N}\end{array}$ & $\begin{array}{r}1.000 \\
303\end{array}$ & $\begin{array}{r}.567^{\wedge} \\
.000 \\
303\end{array}$ \\
\hline & Customer Loyalty & $\begin{array}{l}\text { Correlation Coefficient } \\
\text { Sig. (2-tailed) } \\
\mathrm{N}\end{array}$ & $\begin{array}{r}.567^{\wedge} \\
.000 \\
303\end{array}$ & $\begin{array}{r}1.000 \\
. \\
303\end{array}$ \\
\hline
\end{tabular}

Results on table 3 shows that the relationship between engagement platform and customer loyalty occurred at 0.567 , when the $p$-value is less than 0.05 level of significance: $p(0.000)$ $<0.05$. Hence the null hypothesis was rejected.

\section{Test of Hypotheses (4)}

The focus of this hypothesis was on the idea that engagement platform can improve emotive commitment in Aviation Industry in Nigeria if there exists a significant relationship.

$\mathbf{H}_{\text {04 }}$ : There is no significant relationship between engagement platform and emotive commitment in Aviation Industry in Nigeria.

\section{Table 4.68: Correlation between Engagement Platform and Emotive Commitment} Correlations

\begin{tabular}{|lll|r|r|}
\hline & & $\begin{array}{c}\text { Engagement } \\
\text { Platform }\end{array}$ & $\begin{array}{c}\text { Emotive } \\
\text { commitment }\end{array}$ \\
\hline Spearman's rho & Engagement Platform & Correlation Coefficient & 1.000 & .650 \\
& & Sig. (2-tailed) &. & .000 \\
& $\mathrm{~N}$ & 303 & 303 \\
\cline { 2 - 5 } & Emotive commitment & Correlation Coefficient & $.650^{\prime \prime}$ & 1.000 \\
& Sig. (2-tailed) & .000 &. \\
& $\mathrm{~N}$ & 303 & 303 \\
\hline
\end{tabular}

${ }^{* *}$. Correlation is significant at the 0.05 level (2-tailed).

The result on table 4 from tested hypotheses 4 revealed that engagement platform significantly relate to emotive commitment at 0.650 , when p-value is less than 0.05 level of significance $(\mathrm{p}(0.000)<0.05))$. Therefore, the null hypothesis was rejected as the study accepted that a significant relationship occur between engagement platform and emotive commitment in Aviation Industry in Nigeria. 


\section{Discussion of Findings}

From the first hypothesis, it is expected that personal interaction will enhance customer loyalty. The result from hypotheses 1 revealed that a significant relationship exists between personal interaction and customer loyalty. The work of Yoon, Seo and Yoon (2004), Julian and Ramaseshan (1994) supported this finding. Indeed, Yoon, Seo and Yoon (2004) recommended that firm should engage customers because personal interactions on the service quality will make customers see the clear values embedded in product and services, and this is one of the most significant outcomes attained by communicating with customers. Julian and Ramaseshan (1994) showed that better interaction not only decreases the perceived risk related to the product and service purchase but also increases the knowledge of buying behavior.

With regards to the second hypothesis, personal interaction is expected to enhance emotive commitment. The result from hypotheses 2 also indicates a significant relationship between personal interaction and emotive commitment. Backstrom and Johansson (2006) establish that personal interaction is a service process which occurs from interactions between customers and employees. They see personal interaction as a practice involving people in marketing services. Therefore, good experience through interactions between customers and employees lead to a satisfactory experience which will ensure emotive commitment. This implies that organization that demonstrates politeness, develops quality of acting in a pleasant caring manner; developed sense of deep appreciation for customers have done well by generating value that will increase customers' emotive commitment.

From the finding of the third hypothesis, engagement platform will improve customer loyalty. The result of tested hypotheses 3 shows that engagement platform has a significant relationship with customer loyalty. The work of Nirmali et al. (2001) supports this finding. Nirmali et al. (2001) carried a study on value co-creation and organizational performance in Malaysia. They adopted engagement platform and relates it to organizational performance. The finding shows positive relationship which means that engagement platform improves organizational performance. Therefore, Aviation Industry in Nigeria will increase customer loyalty by developing effective engagement platform.

From hypothesis four, engagement platform is also expected to improve emotive commitment. The result shows a significant relationship between engagement platform and emotive commitment. The work of Sawhney, Verona and Prandelli (2005) Ramaswamy (2009) supports this finding. Sawhney et al. (2005) and Ramaswamy (2009) highlighted engagement platforms as physical or virtual touch points aimed at providing structural strength for resource exchange and integration and thus co-creating value between actors. Engagement platforms focus on instrument of engagement that improves the ability of an actor to achieve great experience. Therefore, effective engagement platform will improve emotive commitment in Aviation Industry in Nigeria.

\section{Conclusion}

The need for value co-creation in achieving customer satisfaction cannot be over emphasized. The study uncovered a significant relationship that exists between value cocreation and customer satisfaction in Aviation Industry in Nigeria. This implies that value co-creation affects customer satisfaction in Aviation Industry in Nigeria. 


\section{Recommendations}

The study made active recommendations to improve customer satisfaction through value cocreation in Aviation Industry in Nigeria.

1. Management should encourage all staff to develop personal interaction with customers to increase customer loyalty in Aviation Industry in Nigeria.

2. Management should build customers' experience through personal interaction to improve customer retention in Aviation Industry in Nigeria.

3. Management should build an effective engagement platform with the aim to maintain personal touch across all online and physical channels to increase customer loyalty in Aviation Industry in Nigeria.

4. Management should involve customers in value co-creation using design flexible engagement platform as tool to accommodate customer experiences thatwill improve emotive commitment in Aviation Industry in Nigeria

\section{Contributions to Knowledge}

The study made strong contributions to streams of research studies on these constructs in literature. The study developed conceptual framework which helps in drawing valid conclusion on how value co-creation affects customer satisfaction thereby enhances knowledge on these concepts in literature. Additionally, the two dimensions of value cocreation as adopted provides a solid foundation for better treatment of value co-creation in literature, especially as it relates to customer satisfaction.

\section{Areas for further Research}

Research on these concepts in the tourism sector is important. However, there are values found in this sector by customers. These values could be identified in beautiful infrastructures, recreational facilities, museums, libraries, cultural displays and Parks which occasionally attract customers' attentions. Customers may find values in these areas and their being satisfied might depend on how well the values meet their expectations. Hence, a research study could be carried out on 'Value Co-creation and Customer loyalty in Tourism firms in Nigeria. Finally, the study is a survey research, and could not examine customers' behaviour of which it can only be studied after a long period of observation since behavior changes over time. Hence, further research may be conducted using longitudinal research design to examine customer behaviour if it has been affected over time by value co-creation. 


\section{References}

Backstrom, J. \& Johansson, U. (2006). Creating and consuming experiences in retail store environments: Comparing retailer and consumer perspectives. Journal of Retailing and Consumer Services, 13, 417-430.

Ballantyne, D. \& Varey, R. J. (2006). Creating value-in-use trough marketing interaction: The exchange logic of relating, communicating and knowing. Marketing Theory, 6(3), 335-348. doi 10.1177/1470593106066795

Bansal, H. S., Gregory, P., Irving, S. F \& Taylor, A. (2004). Three-component model of customer commitment to service providers. Academy of Marketing Science. Journal, 32(3), 234-250.

Bowers MR, Martin CL (2007). Trading places redux: employees as customers, customers as employees, Journal of Service Marketing, 21(2), 88-98.

Bowley, A. L. (1964). Measurements of precision attained in sampling. Bulletin. International Statistics Institutions. Amsterdam, 22, 1-62.

Chu S., Kim Y. (2011). Determinants of consumer engagement in electronic word-of-mouth (eWOM) in social networking sites. International Journal of Advertisement,30, 47-75. 10.2501/IJA-30-1-047-07'

Cova, B. \& Dalli, D. (2009). Working Consumers: The Next Step in Marketing Theory? Marketing Theory, 9(3), 315-39.

Cronbach, L. J. (1951). Coefficient alpha and the internal structure of tests. Psychometrika, 16(3), 297-334.

Dong, B., Evans, K. R., \& Zou, S. (2007). The effects of customer participation in cocreated service recovery. Journal of the Academy Marketing Science, 36, 123-137.

Fisher, D. \& Smith S. (2011). Co creation is chaotic: What it means for marketing when no one has control. Marketing theory, 11(3), 325 - 350.

Fullerton, G. (2005). The impact of brand commitment on loyalty to retail service brands, Canadian Journal of Administrative Sciences,22(2), 97-110.

Grönroos, C. (2000). Service management and marketing: a customer relationship management approach. West Sussex, UK: John Wiley \& Sons.

Gummesson, E. (2008). Total Relationship Marketing, 3rd ed. Oxford, UK: Elsevier.

Gummesson, E. (2009). B2B is not an island. Journal of Business \& Industrial Marketing, 24(5/6), 337-350.

Gruen, T.W., Summers, J.O. \&Acito, F. (2000). Relationship Marketing Activities,

Harris, A. (2007). Distributed leadership: conceptual confusion and empirical reticence', International Journal of Leadership in Education, 10(3), 1-11.

Julian, C.C. \& Ramaseshan, B. (1994). The role of customer-contact personnel in the marketing of a retail bank's services. International Journal of Retail and Distribution Management, 5, 9-34. 
Kau, A.K., \& Loh, E.W. (2006). The effects of service recovery on consumer satisfaction: A comparison between complainants and non-complainants. The Journal of Services Marketing, 20(2), 101-111.

Kincaid, D. (2003). Consumer Idealized Design: Involving Consumers in theProduct Development Process. Journal of Product Innovation Management, 1(4), 341-347.

Kotler, P. \& Keller, K. L. (2009). Marketing management (13th ed.). New Jersey: Pearson Prentice Hall.

Lee, K. \& Thorson, R. (2008). The Customer satisfaction and the Future of Marketing. Journal of the Academy of Marketing Science,3(6), 11-14.

Lee, S.M., Olson, D.L., \& Trimi, S. (2012). Co-innovation: convergenomics, collaboration, and co-creation for organizational values. Management Decision, 50(5), 817 - 831.

Mc-Coll Kennedy, D., Vargo, S.L., Dagger, R., Sweeney, M \& Van, K. (2012). Communities of Practice and articles, Organization, 2(2), 225-246.

Neghina, P., Caniels, A.F., Bloemer, K. \& Van, B. (2014). Managing the co-creation of value. Journal of Academic Marketing Science, 3(6), 83-96.

Nenonen, S., \& Storbacka, K. (2010). Business model design: Conceptualizing networked value co-creation. International Journal of Quality and Service Sciences, 2(1), 43-59.

Nirmali, A., Yajid, M.S. \& Azam, F. (2001). Value co-creation and organizational performance in Malaysia, 3-7.

Okwandu, G.A. (2006). Research methods in business and social sciences, Owerri, Nigeria. Civinics publishers.

Payne, A., Storbacka, K. \& Frow, P. (2008). Managing the co-creation of value', Journal of the Academy of Marketing Science, 36, 83-96.

Prahalad, C.K. \& Ramaswamy, V. (2004). Co-production and customer loyalty in financial services. Journal of Retailing,3(3), 359-370.

Ramaswamy, V. \& Gouillart, F. (2010). The Power of Co-creation. New York: The Free Press.

Ramaswamy, V. \& K. Ozcan (2014). The Co-Creation Paradigm. Redwood City, CA: Stanford University Press.

Ramaswamy, V. \& K. Ozcan (2014). The Co-Creation Paradigm. Redwood City, CA: Stanford University Press.

Ramaswamy, V., (2009). Leading the transformation to co- creation of value. Strategy \& Leadership, 37(2), 32-37.

Sawhney, M., Verona, G. \& Prandelli, M., (2005). Collaborating to create: the Internet as a platform for customer engagement in product innovation. Journal of Interactive Marketing, 19(4), 2-6 
Spector, P. (2008). Industrial and organizational psychology: Research and practice(5th ed.). New York: John Wiley \& Sons.

Spreng, A. R., Harrell, G. \& Mackoy, D. R. (1995). Service recovery: Impact on satisfaction and recovery, Journal of Services Marketing, 9(1), 15-23.

Srinivasan, S., \& Hanssens, D. M. (2009). Marketing and firm value: Metrics, methods, findings, and future directions. Journal of Marketing Research, 46(3), 293-312.

Stone, P. (2000). Consumers as resource integrators. Journal of Marketing Management, 1(2), 113-193.

Troccoli, P. \& Altaf, A. (2012). Customer voluntary performance: Customers as partners in service delivery. Journal of Retailing, 3(3), 383-406.

Troccoli, P. (2010). Human-Centered Design Methodology. Proceedings from Design Research in the Netherlands, 23-32.

Vilares, E., Kell, C. \& Voima, P. (2001). Satisfying customers need. Journal of Academic Marketing Science,4(1), 133-150.

Yamane, T. (1967). Statistics: An Introductory Analysis, 2nd Ed., New York: Harper and Row.

Yoon, M.H, Seo, J.H. \& Yoon, T.S. (2004). Effect of contact employee supports on critical employee responses and customer service evaluation. Journal of service Marketing, $18(5), 395-412$. 